\title{
UMA CRÍTICA HUMANISTA À IDEOLOGIA UUNICA GLOBALIZADA
}

\section{Por Maria Ceci Misoczky}

Professora e pesquisadora do Programa de Pós-Graduação em Administração - EA/ UFRGS

E-mail: mcaraujo@ea.ufrgs.br

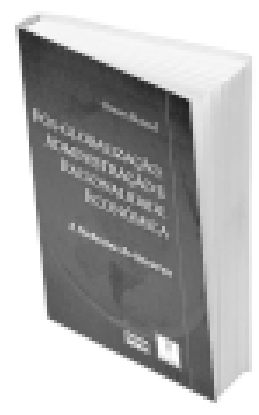

\section{PÓS-GLOBALIZAÇ̃̃O, ADMINISTRAÇ̃O E RACIONALIDADE ECONÔMICA: A SÍNDROME DO AVESTRUZ}

De Omar Aktouf

São Paulo: Editora Atlas, 2004. 1ạ edição, 297 p.
Este livro de O mar Aktouf retoma as idéias que se encontravam presentes em $A$ administração entre a tradição e a renovação, editado pela Atlas em 1996. É a mesma crítica, a partir de um humanismo claramente expresso, ao modo como as pessoas são penalizadas pela disseminação de idéias e práticas que legitimam a racionalidade do lucro sem limites, e o mesmo desejo de indicar caminhos para que os seres humanos se realizem no trabalho, simultaneamente à preservação do planeta. Essa constatação inicial evidencia um autor que não se deixa levar por modismos, eque persiste de modo íntegro na defesa de seus princípios.

Esta nova obra aproxima a Economia da Administração, buscando os vínculos conceituais e empíricos entre as perspectivas que dominam esses campos de conhecimento e aquilo que denomina de ideologia única globalizada. Numa linguagem sempre muito direta, que às vezes pode dar a falsa impressão de expressar um raciocínio simplista, o autor inicia o livro denunciando os pontos que compõem a argumentação neoliberal, uma retórica que naturaliza- "uma série de absurdos e mesmo infâmias que ocorrem no mundo real" (p. 48). Esse capítulo se encerra com a seguinte questão: como a Economia - e posteriormente a Administração - se transformou em instrumento dessa construção de argumentos cínicos?

Em busca de respostas, Aktouf recorre a Aristóteles e à distinção entre o conceito de economia, que secaracteriza como norma de conduta do bem-estar na comunidade, e o de crematística, que se caracteriza como a acumulação de meios de aquisição. A reflexão avança para apontar o que 0 autor denomina configuração heréti- ca da mentira: a traição por parte dos especialistas, quefazem passar por econômico o que é apenas crematístico, excluindo, dessa forma, qualquer possibilidade de consideração moral ou ética. As prescrições de Michael Porter são utilizadas como ilustração dessa traição, bem como da aliança que se dá entre a Economia e a Administração made in USA, "o braço armado do pensamento econômico dominante" (p. 124). Trata-se da disseminação de uma ideologia maximizante e belicista, que justifica uma corrida por vantagens egoístas e que desconsidera a finalidade humana da atividade econômica. Ao abordar o pensamento de Porter, Aktouf introduz a crítica ao uso irrefletido e abusivo do método "do caso" no ensino da Administração, descrito como "empírico-indutivismo ideológico” (p. 80).

No capítulo seguinte, há uma reflexão em torno de práticas da Eco- 
nomia tradicional, especialmente aquelas que ocorrem nos bazares de países orientais eárabes. A partir dessas origens culturais, Aktouf mostra que no mercado existem práticas que não são orientadas exclusivamente para a multiplicação do dinheiro pelo dinheiro.

0 argumento se desloca, então, na direção de explicações sobre o surgimento dessa Administração de origem americana que se dissemina como se tivesse um caráter universal, sobre as ligações que ela mantém com os meios financei ros dominantes e com a ideologia neoliberal, e sobre as práticas que ela autoriza e as conseqüências que gera. Para fazêIo, o autor conta a história da ligação entre a extração de mais-valia e a Administração. Nessa narrativa, al guns marcos e sucessivos fracassos ganham destaque, tais como: Taylor e F ayol, inevitavelmente; o comportamento organizacional em busca de refinar os modos de manipular percepções; a Administração pela excelência em busca de manipular a subjetividade e as energias libidinais; a redução exponencial do custo do trabalho por meio de reduções maciças nos efetivos e da simultânea superexploração daqueles que permanecem nos postos de trabal ho. Essa última prática Aktouf denomina "formato extremo da mais-valia relativa, [... ] retorno à crueldade da mais-valia absoluta do século XIX" (p. 137).

A culminação desse processo é abordada no capítulo que discorre sobre a Administração como casuística, a disseminação do gerencialismo - tratado como campo de concretização do economicismo - e a legitimação do enriquecimento infinito dos mais ricos. A crítica ao método de casos é retomada, denunciando agora os seguintes pontos: sua função heurística de reproduzir o discurso e a ideologia dos dirigentes de negócios; sua função didática de condicionar a ação tendo como objetivo e justificação a rentabilidade financeira; sua função pedagógica de desenvolver reflexos de escol has rápidas entre catálogos de decisão de orientação pragmática e maximizante. N esse contexto, trata-se da supremacia absoluta da crematística.

Dessa forma, 0 autor produz um capítulo que busca conexões entre as leis formuladas pelo pensamento marxista e indicações que se originam nas ciências físicas e na termodinâmica, com o objetivo de argumentar que o crescimento não pode ser infinito. Ao se aceitar essa idéia é necessário aceitar que o modelo de Administração que recomenda a busca do lucro máximo em mercados auto-regulamentados e de concorrência ilimitada precisa ser revisto. A dupla extração contínua e exponencial - do trabalho no ambiente interno e dos recursos naturais no ambiente externo - coloca em risco as condições da própria continuidade da humanidade e do planeta.

Em busca de indicações sobre a maneira de redirecionar a Economia ea Administração a partir de uma atitude humanista, Aktouf retoma as críticas às teorias que visam fabricar a adesão, em suas diversas vertentes. Afinal, que "ser humano" essas teorias visam promover? Em contraposição, o autor apresenta uma "concepção humana do homem, e do homem no trabalho" (p. 213). A partir de referências que incluem Aristóteles, Weber, M arx, Fromm, Sartre, Marcuse, Freud e EvansPritchard, são formuladas algumas idéias-chave, entre as quais se destacam: 0 ser humano destina-se à busca do que o liberta e o conduz à realização, sendo criador do seu meio e de si mesmo; o ser humano possui uma natureza sociocomunitária irremovível; simultaneamente, o traba-
Iho é o lugar onde o ser humano corre o risco de perder sua humanidade rumo à al ienação e o lugar onde pode expressar sua essência de criador. Adotar esse humanismo justifica o questionamento da ordem estabelecida, o apelo contra a fragmentação e a perda de sentido do trabalho, a crítica às práticas administrativas como obstáculos à realização dos seres humanos no trabal ho, o questionamento do economicismo e do utilitarismo estreitos.

A té este ponto, esta resenha é escrita em total harmonia com os argumentos desenvolvidos pelo autor. No entanto, do mesmo modo que ocorria com o livro anterior de Aktouf, considero que o esforço e a competência da crítica se desgastam com a tentativa, tão própria da Administração, de realizar alguma prescrição. As práticas de gestão dos países germano-escandinavos e do Japão são, mais uma vez, apresentadas como referências de métodos de obtenção e sustentação de consenso, onde o empregado é tratado como parceiro e o meio ambiente é preservado. Ainda que o autor reconheça que as práticas não são as mesmas quando as corporações que se originam nesses países se localizam em países do sul do planeta, permanece a mitificação desses modelos de gestão. Não é demais lembrar que Fernando Prestes M otta e M aurício Tragten berg chamaram a atenção à contribuição de alguns desses métodos para 0 aumento na extração de mais-valia e para a fabricação da adesão.

A pesar dessa limitação, o livro de O mar Aktouf é extremamente valioso. É sempre recomendável refletir sobre o que se está legitimando ao disseminar ou produzir idéias. Sem essa refl exão estaremos deixando de lado nossa plenitude enquanto seres humanos, não exercendo nossa humanidade. 